\title{
Caffeine Decreases Zinc and Metallothionein Levels in Heart of Newborn and Adult Rats
}

\author{
MAGDALENA J. ROSSOWSKA AND TETSUO NAKAMOTO \\ Laboratory of Perinatal Nutrition and Metabolism, Department of Physiology, Louisiana State University \\ Medical Center, New Orleans, Louisiana 70119
}

\begin{abstract}
The purpose of the present study is to show that dietary caffeine, heart tissue $\mathrm{Zn}$ levels, and metallothionein (MT) concentration are all interrelated in newborn rats. Dams with eight pups in the control group were fed a $20 \%$ protein diet upon delivery, whereas dams in the experimental group were fed a $20 \%$ protein diet supplemented with caffeine ( $2 \mathrm{mg} / 100 \mathrm{~g}$ body weight). Offspring were killed at $d 22$ postbirth and the hearts and livers were removed to determine the $\mathrm{Zn}$ and $\mathrm{MT}$ concentrations. Hearts of the newborn rats in the caffeine group showed decreased $\mathrm{Zn}$ levels as well as decreased MT concentration. To explain the observed effects in newborn rats, the relationship between $\mathrm{Zn}$ and MT levels was studied in adult female rats. They were injected intraperitoneally with either $\mathrm{ZnCl}_{2}(20 \mathrm{mg} / \mathrm{kg}$ body weight) dissolved in saline solution or $\mathrm{ZnCl}_{2}$ and caffeine $(4 \mathrm{mg} / \mathrm{kg}$ body weight) over a period of $2 \mathrm{~d}$. Injection of $\mathrm{ZnCl}_{2}$ into adult female rats resulted in an increase in heart MT levels, whereas injection of caffeine caused decreased $\mathrm{Zn}$ levels and MT concentration. Current findings indicate that dietary caffeine intake during the lactational period by newborn pups causes a decrease of the heart $\mathrm{Zn}$ and MT levels. (Pediatr Res 32: 330-332, 1992)
\end{abstract}

Abbreviations

MT, metallothionein

i.p., intraperitoneal

SF, supernatant fraction

Direct caffeine injection into the femoral vein in adult rats has resulted in a decrease in heart $\mathrm{Zn}$ levels within a short time (1). A caffeine-supplemented diet fed to postweaning young rats also has caused a decrease of $\mathrm{Zn}$ and $\mathrm{Ca}$ tissue levels in their hearts compared with the noncaffeine control group (2). $\mathrm{Zn}$ is essential to growth and development $(3,4)$. It has been shown that $\mathrm{Zn}$ deficiency produces abnormal development (5). Because $\mathrm{Zn}$ plays an important role in membrane structure and function (6), this decrease in $\mathrm{Zn}$ and MT levels in the heart could have implications in the developmental process of the heart. Impairment of function of the growing rat heart as a result of chronic caffeine intake during the neonatal period has been documented (7).

MT is a low-molecular weight, cysteine-rich cytoplasmic (supernatant) protein that binds divalent metals and has a high affinity for $\mathrm{Zn}$. It has been shown that the increases in SF Zn and $\mathrm{Cu}$ contents are well correlated with enhanced MT synthesis

Received September 16, 1991; accepted May 12, 1992.

Correspondence: Dr. M. J. Rossowska, Department of Physiology, Louisiana State University Medical Center, 1100 Florida Ave., New Orleans, LA 70119.

Supported in part by Grant BRSG SO7 RR05704-15, DRR NIH.
(8). Inasmuch as the heart of the newborn rat is growing during the lactational period, as is shown by the increase of DNA content (9), it is conceivable that maternal caffeine intake during this period could affect $\mathrm{Zn}$ tissue levels in the hearts of their offspring through suckling milk and/or could alter the composition of the milk, which in turn may cause changes in cardiac $\mathrm{Zn}$ levels. The objective of the present study is to determine how chronic caffeine intake by newborn rats affects MT concentration through the tissue $\mathrm{Zn}$ levels in the heart. We have measured the $\mathrm{Zn}$ and MT contents of the liver and the heart to compare the different effects of caffeine on these organs. MT content of the liver is well established in the literature, whereas the information on MT content of the heart of newborn rats is limited at the present time.

\section{MATERIALS AND METHODS}

Effect of chronic caffeine intake by dams and their newborn rats. Timed-pregnant rats were obtained from a commercial breeder (Holtzman Co., Madison, WI). At term, litters delivered within an $8-\mathrm{h}$ period were combined and designated $\mathrm{d} 1$; eight pups were randomly assigned to each dam. Pup assignment was made without regard to the sex of the pups.

The control dams $(n=6)$ were fed a $20 \%$ protein diet ad libitum to determine the mean daily food intake and body weight changes from $\mathrm{d} 1$. The caffeine dams $(n=6)$ were fed a $20 \%$ protein diet supplemented with caffeine, in amounts calculated to provide $2 \mathrm{mg} / 100 \mathrm{~g}$ body weight to the dams. The dietary. composition of the $20 \%$ protein diet has been described (10). The calculated concentration of $\mathrm{Zn}$ was $12 \mathrm{mg} / \mathrm{kg}$ diet.

On d 22, dams and their pups from each group were killed between 0900 and $1100 \mathrm{~h}$ by decapitation. The livers and hearts were removed, blotted, and weighed. Hearts were homogenized in $0.25 \mathrm{M}$ cold sucrose, $10 \mathrm{mM}$ Tris- $\mathrm{HCl}, \mathrm{pH} 7.4$, for $30 \mathrm{~s}$ using a Polytron homogenizing apparatus (model SDT, Tekmar Co., Cincinnati, $\mathrm{OH}$ ) at a setting of half-maximal speed. Livers were homogenized in $0.25 \mathrm{M}$ sucrose, $10 \mathrm{mM}$ Tris- $\mathrm{HCl}, \mathrm{pH} 7.4$, in a glass Teflon homogenizer. All procedures were carried out at $4^{\circ} \mathrm{C}$. The homogenates were centrifuged (model RC-2B Sorvall centrifuge, SS-34 rotor; Dupont, Newtown, CT) at $45000 \times g$ for $30 \mathrm{~min}$ at $4^{\circ} \mathrm{C}$. SF were collected.

Generally, 1-mL homogenates and 2-4-mL SF, which were evaporated to $1 \mathrm{~mL}$, were used to determine the $\mathrm{Zn}$ content by atomic absorption spectrophotometry (model 280; Fisher Scientific Co., Fair Lawn, NJ). Concentrated nitric acid (1 mL) was added to $1 \mathrm{~mL}$ of homogenate in a tightly capped tube and samples were left at room temperature for $24 \mathrm{~h}$ followed by digestion at $100^{\circ} \mathrm{C}$ overnight. Digested samples were diluted in deionized double-distilled water and $\mathrm{Zn}$ concentration was measured. Standard reference solution was purchased commercially (Fisher Scientific Co.). Supernatants were analyzed for MT concentration with cadmium heme saturation assay (11). MT was calculated according to a molecular weight of 6800 and the definite molar ratio of $7 \mathrm{~mol}$ of $\mathrm{Cd} / \mathrm{mol}$ of MT (12). Because of 
a high affinity for $\mathrm{MT}$, the existence of $\mathrm{Cu}$ will lead to an underestimation of MT by the Cd saturation method. Under normal conditions, however, this limitation of the assay is considered to be negligible. Treatment with neither caffeine nor $\mathrm{Zn}$ led to significant changes in the $\mathrm{Cu}$ content of the experimental samples (data not shown).

Acute caffeine effects on adult rats. Adult female SpragueDawley rats (Holtzman strain; Holtzman Co.), 250-300 g, were used for all experiments. Animals were maintained on a 12 -h light/dark cycle for at least $3 \mathrm{~d}$ after arrival before being used in experiments. Before and during the experiments, the animals had access to commercial diet containing $70 \mathrm{mg}$ of $\mathrm{Zn} / \mathrm{kg}$ (Rodent Chow 5001; Purina Mills, St. Louis, MO) ad libitum.

Animals were then randomly divided into five groups. Group 1 (control) received no treatment. Group 2 (Zn-treated) received $0.5-\mathrm{mL}$ i.p. injections of $\mathrm{ZnCl}_{2}(20 \mathrm{mg} / \mathrm{kg}$ body weight) (Sigma Chemical Co., St. Louis, MO) dissolved in $0.9 \%$ physiologic saline solution at 0 and $6 \mathrm{~h}$. In addition, at 2, 4, and $8 \mathrm{~h}, 0.5 \mathrm{~mL}$ of saline solution was injected. This was repeated the next day on the same time schedule. Thus, the animals received a total of four $\mathrm{Zn}$ solution injections.

Group 3 ( $\mathrm{Zn} \pm$ caffeine-treated) received 0.5-mL i.p. injections of caffeine ( $4 \mathrm{mg} / \mathrm{kg}$ body weight) (Sigma Chemical Co.) $+\mathrm{ZnCl}_{2}$ $(20 \mathrm{mg} / \mathrm{kg}$ body weight) dissolved in physiologic saline at 0 and $6 \mathrm{~h}$. At 2,4 , and $8 \mathrm{~h}, 0.5 \mathrm{~mL}$ of caffeine alone $(4 \mathrm{mg} / \mathrm{kg}$ body weight) in saline solution was injected. The injections were repeated the next day on the same time schedule, with a total of 10 caffeine injections, four of which contained $\mathrm{Zn}$ solution as well. All animals received an initial injection between 0800 and $0900 \mathrm{~h}$. All animals of groups 1, 2, and 3 were killed $48 \mathrm{~h}$ after the initial injection.

The injection schedules of groups 4 and 5 were as follows. For the first $48 \mathrm{~h}$, the animals of groups 4 and 5 were on the same schedule as the animals in group 2 . Then, at $48 \mathrm{~h}$ from the initial injection, group 4 ( $\mathrm{Zn}$-treated + saline) received a single dose of $0.5 \mathrm{~mL}$ of saline i.p. Group 5 (Zn-treated + caffeine) received a single dose of $0.5 \mathrm{~mL}$ of caffeine solution $(16 \mathrm{mg}$ of caffeine $/ \mathrm{kg}$ body weight dissolved in physiologic saline). Animals were killed $24 \mathrm{~h}$ later ( $72 \mathrm{~h}$ after initial injection).

All rats were killed by decapitation. Blood was collected in heparinized tubes. The content of $\mathrm{Zn}$ was measured in serum by atomic absorption spectrophotometry. Hearts only were analyzed for $\mathrm{Zn}$ and MT content. Tissue was cut into small pieces, homogenized, and analyzed according to the procedures described before.

Protein concentration was determined according to the method of Lowry et al. (13), using BSA as a standard. The data were analyzed using the $t$ test, an analysis of variance, and a multiple comparison (Student-Newman-Keuls) with $5 \%$ considered significant.

\section{RESULTS}

$\mathrm{Zn}$ concentrations in the heart homogenate and in its SF in the newborn rats were less in the caffeine group than in the control group (Table 1). In contrast, $\mathrm{Zn}$ concentration in the liver showed no differences between the groups.

MT concentrations in the SF obtained from homogenate hearts and livers of the newborn rats are shown in Table 2. MT concentration in the heart was less in the caffeine group than in the control group, whereas MT concentration in the liver showed no difference between the groups.

Zn concentrations in the SF in group 2 (Zn-treated) and group 3 ( $\mathrm{Zn}+$ caffeine-treated) were higher than in those of the control group (group 1). Zn concentration in the SF in group 3 was less than in group 2 (Table 3 ). Zn concentrations in the SF in group 4 (Zn-treated + saline) and group 5 ( $\mathrm{Zn}$-treated + caffeine) after $24 \mathrm{~h}$ were less than in those of group 2 . Supernatant $\mathrm{Zn}$ content in group 4 showed no difference from that of group 5 and no statistically significant difference from control (group 1). Serum
Table 1. Zn concentration in heart and liver of 22-d-old pups*

\begin{tabular}{ccc}
\hline Fraction & Control & Caffeine \\
\hline Heart & & \\
Homogenate & $206.5 \pm 8.0$ & $155.7 \pm 5.6 \dagger$ \\
& $(6)$ & $(5)$ \\
Supernatant & $240.7 \pm 7.0$ & $187.3 \pm 15.2 \dagger$ \\
& $(5)$ & $(5)$ \\
Liver & & \\
Homogenate & $202.6 \pm 9.8$ & $198.8 \pm 7.5$ \\
Supernatant & $(6)$ & $(5)$ \\
& $435.6 \pm 17.4$ & $424.6 \pm 42.2$ \\
& $(6)$ & $(5)$ \\
\hline
\end{tabular}

* Values are expressed in nmol/100 mg of protein and represent mean $\pm \mathrm{SEM}$; number of samples determined is given in parentheses.

$\uparrow$ Mean values significantly different from those of the controls at $p<$ 0.05 .

Table 2. MT concentration in SF obtained from homogenate heart and liver of 22-d-old pups*

\begin{tabular}{ccc}
\hline Tissue & Control & Caffeine \\
\hline Heart & $3.35 \pm 0.41$ & $1.68 \pm 0.11 \uparrow$ \\
& $(5)$ & $(5)$ \\
Liver & $22.59 \pm 3.54$ & $22.01 \pm 2.80$ \\
& $(6)$ & $(5)$ \\
\hline
\end{tabular}

* Values are expressed in nmol/100 $\mathrm{mg}$ of protein in $\mathrm{SF}$ and represent mean \pm SEM; number of samples determined is given in parentheses.

$\dagger$ Mean values significantly different from those of the controls at $p<$ 0.05 .

Table 3. Zn and MT concentration in SF of heart of adult rats in different groups*

\begin{tabular}{lcc}
\hline \multicolumn{1}{c}{ Groups } & $\mathrm{Zn}$ & $\mathrm{MT}$ \\
\hline Control $\dagger(\mathrm{G} 1)$ & $175.6 \pm 24.3$ & $1.42 \pm 0.11$ \\
& $(5)$ & $(5)$ \\
Zn-treated (G2) & $385.7 \pm 12.3 \ddagger$ & $13.75 \pm 0.89 \ddagger$ \\
& $(4)$ & $(3)$ \\
Zn + caffeine-treated (G3) & $298.8 \pm 26.9 \ddagger \S$ & $9.11 \pm 0.65 \ddagger \S$ \\
& $(4)$ & $(3)$ \\
Zn-treated + saline $\|(G 4)$ & $236.0 \pm 8.4 \S$ & $9.61 \pm 1.14 \ddagger \S$ \\
& $(3)$ & $(3)$ \\
Zn-treated + caffeine $\|(G 5)$ & $237.5 \pm 10.3 \S$ & $9.18 \pm 1.58 \ddagger$ \\
& $(3)$ & $(3)$ \\
\hline
\end{tabular}

* Values are expressed in $\mathrm{nmol} / 100 \mathrm{mg}$ of protein in $\mathrm{SF}$ and represent mean $\pm \mathrm{SEM}$; number of samples determined is given in parentheses. $\mathrm{G}$, group.

† Our preliminary studies showed that animals treated with multiple injections of saline did not differ from untreated controls in their $\mathrm{Zn}$ and MT levels; therefore, control rats in this study were untreated so that comparison could be made with endogenous levels of $\mathrm{Zn}$ and MT.

$\$$ Mean values significantly different from those of the controls (G1) at $p<0.05$.

$\S$ Mean values significantly different from those of the $\mathrm{Zn}$ group $(\mathrm{G} 2)$ at $p<0.05$.

$\| \mathrm{G} 4$ and G5 were treated the same as G2 for the first $48 \mathrm{~h}$. At $48 \mathrm{~h}$, a single injection of either saline or caffeine was done. Then $24 \mathrm{~h}$ later these animals were killed ( $72 \mathrm{~h}$ after initial injection).

$\mathrm{Zn}$ concentration showed an increase in groups 2 and $3 . \mathrm{Zn}$ concentration of serum showed no differences between groups 4 and 5 after $24 \mathrm{~h}$ (data not shown).

MT concentrations in group 2 and group 3 were higher than that in group 1. MT concentration in group 3 was less than in group 2 (Table 3). MT concentration in group 4 was still more than that of group 1, whereas this value in group 4 was less than in group 2. On the other hand, groups 4 and 5 showed no difference in MT concentration. 


\section{DISCUSSION}

MT occurs in high concentrations in the livers of fetal and newborn animals $(14,15)$. In the newborn rats $(1$ and $7 \mathrm{~d})$, the hepatic MT concentrations were extremely high (about 98 times adult values) and decreased steadily to adult values by $\mathrm{d} 28$ postpartum (16). MT concentrations in heart were comparable with adult values by $3 \mathrm{wk}$ after birth (16). In our present study, the levels of liver MT in the newborn rats $(22 \mathrm{~d}$ old) were about 10 times more than those of the dams (data are not shown). It is conceivable that MT in the livers of the newborn rats could provide a reserve for $\mathrm{Cu}$ and $\mathrm{Zn}$ metals that can be used during the period of rapid postnatal growth. The demand for these metals is not only high, but it is also possibly greater than the supply from the maternal milk $(17,18)$.

Correlation between $\mathrm{Zn}$ status and the role of MT has been investigated in different tissues. It has been shown that $\mathrm{Zn}$ injection and changes in dietary $\mathrm{Zn}$ induce the synthesis of $\mathrm{Zn}$ thionein in liver (19). Although the hearts of 7-d-old rats (16) and adult rats (20) have not shown increases in MT after $\mathrm{Zn}$ treatment, it was later shown that $\mathrm{Zn}$ is the most effective indicator of MT synthesis in the heart $(21,22)$.

Our hypothesis was that caffeine might have affected $\mathrm{Zn}$ tissue content of the pups, which in turn would have impaired MT levels. Caffeine injection has been shown to decrease the $\mathrm{Zn}$ tissue levels of the hearts (1). In the present study, a decrease in $\mathrm{SF} \mathrm{Zn}$ in the heart of the pups in the caffeine group was correlated with a decrease in observed MT levels. The $\mathrm{Zn}$ concentration and MT levels of livers showed no difference between the caffeine and noncaffeine groups.

If MT is involved in $\mathrm{Zn}$ metabolism, either as a major storage site for $\mathrm{Zn}$ or as a component of the homeostatic control mechanisms for total organ $\mathrm{Zn}$, or both, then synthesis, as well as catabolism of this protein, is an important factor in the regulation process. Under certain conditions, $\mathrm{Zn}$ stored as $\mathrm{Zn}$-thionein could become metabolically available. It has been shown that $\mathrm{Zn}$ bound to MT is mobilized during a metabolic need for $\mathrm{Zn}(23)$.

We have conducted experiments using adult rats and studied the relationship between caffeine and MT content to explain the phenomena observed in newborn rats. After i.p. injection of $\mathrm{Zn}$ (group 2), there was a 10-fold increase in MT $48 \mathrm{~h}$ later. The injection of two times $20 \mathrm{mg} / \mathrm{kg}$ body wt $/ \mathrm{d}$ of $\mathrm{ZnCL}_{2}$ seems to exert maximal effectiveness of the metal to induce MT at the time point selected. If the injection of metal increases MT levels as has been shown, simultaneous injection of $\mathrm{Zn}$ and caffeine (group 3) could possibly interfere with and/or decrease the accumulation of $\mathrm{Zn}$ levels in the hearts, which in turn could affect MT levels. In fact, our data have shown that MT levels in group 3 were less than those in group 2 .

The effects of caffeine on the tissue $\mathrm{Zn}$ levels are relatively short-lived, inasmuch as the $\mathrm{Zn}$ content in the SF showed no differences between $\mathrm{Zn}$-treated + saline (group 4) and $\mathrm{Zn}$-treated + caffeine (group 5) after $24 \mathrm{~h}$.

Correlations between caffeine intake, $\mathrm{Zn}$ levels, and MT content support a role for $\mathrm{Zn}$ in the regulation of MT levels in the heart. Binding of metal is necessary for maintenance of the conformational integrity of this protein (23), and metals could stabilize thionein polypeptides in the heart. Thus, caffeine-induced metal loss in the heart could increase the susceptibility of MT to proteolysis. We propose that caffeine-induced metal loss in the heart could influence MT levels in the heart, but more data concerning the metal content of MT should be studied in the future. The present study demonstrated for the first time that maternal dietary caffeine intake during the lactational period decreased $\mathrm{Zn}$ and MT levels in the hearts of the newborn rats. This decrease in MT levels could possibly be related to synthesis and/or degradation of MT as a result of Zn content after chronic caffeine intake by the neonates.

Acknowledgments. The authors thank G. Young, Dr. K. Hashimoto, and M. Higgins, Editorial Consultant, for their assistance.

\section{REFERENCES}

1. Rossowska MJ, Nakamoto T 1990 Effect of caffeine on zinc absorption and zinc concentration in rat tissue. Br J Nutr 64:553-559

2. Rossowska MJ, Dinh C, Gottschalk SB, Yazdani M, Sutton III FS, Nakamoto $T 1990$ Interaction between caffeine intake and heart zinc concentrations in the rats. Br J Nutr 64:561-567

3. Halsted JA, Smith JC, Irvin MI 1974 A conceptus of research on zinc requirements of man. J Nutr 104:347-378

4. Hurley LS 1969 Zinc deficiency in the developing rats. Am J Clin Nutr 22:1332-1339

5. Keen CL, Hurley LS 1989 Zinc and reproduction: effect of deficiency on fetal and postnatal development. In: CF Mills (ed) Zinc and Human Biology. Springer Verlag, New York, pp 183-220

6. Bettger WJ, O'Dell BL 1981 A critical physiological role of zinc in the structure and function of biomembranes. Life Sci 28:1425-1438

7. Temples TE, Geoffray DJ, Nakamoto T, Hartman AD, Miller HI 1987 Effect of chronic caffeine intake on myocardial function during early growth. Pediatr Res 21:391-395

8. Richards MP 1989 Recent developments in trace element metabolism and function. Role of metallothionein in copper and zinc metabolism. J Nutr 119:1062-1070

9. Winick M, Noble A 1965 Cellular response in rats during malnutrition at various ages. Dev Biol 12:451-466

10. Nakamoto $T$, Shaye $R 1986$ Protein-energy malnutrition in rats during pregnancy modifies the effects of caffeine on fetal bones. J Nutr 116:633-640

11. Onosaka S, Cherian MG 1982 Comparison of metallothionein determination by polarographic and cadmium-saturated methods. Toxicol Appl Pharmacol 63:270-274

12. Winge DR, Miklossy KA 1982 Domain nature of metallothionein. J Biol Chem 257:3471-3476

13. Lowry OH, Rosebrough NJ, Farr AL, Randall RJ 1951 Protein measurement with the Folin phenol reagent. J Biol Chem 193:265-275

14. Bakka A, Webb M 1981 Metabolism of zinc copper in the neonate: Changes in the concentrations and contents of thionein-bound $\mathrm{Zn}$ and $\mathrm{Cu}$ with age in the livers of the newborn of various mammalian species. Biochem Pharmacol 30:721-725

15. Ohtake H, Hasegawa K, Koga M 1978 Zinc-binding protein in the livers of neonatal, normal and partially hepatectomized rats. Biochem J 174:999_ 1005

16. Waalkes MP, Klaassen CD 1984 Postnatal ontogeny of metallothionein in various organs of the rat. Toxicol Appl Pharmacol 74:314-320

17. Tearao T, Owen CA 1977 Copper metabolism in pregnant and postpartum rats and pups. Am J Physiol 232:E172-E179

18. Webb M 1979 Function of hepatic and renal metallothioneins in the control of the metabolism of cadmium and certain other bivalent cations. In: Kagi JHR, Nordberg M (eds) Metallothionein. Birkauser Verlag, Stuttgart, pp 313-320

19. Bremner I, Davies NT 1975 The induction of metallothionein in rat liver by zinc injection and restriction of food intake. Biochem J 149:733-738

20. Onosaka S, Cherian MG 1982 The induced synthesis of metallothionein in various tissues of rats in response to metal. II. Influence of zinc status and specific effect on pancreatic metallothionein. Toxicology 23:11-20

21. Satoh M, Naganuma A, Imura N 1988 Involvement of cardiac metallothionein in prevention of adrimycin induced lipid peroxidation in the heart. Toxicology 53:231-237

22. Waalkes MP, Klaassen CD 1985 Concentration of metallothionein in major organs of rats after administration of various metals. Fundament Appl Toxicol 5:473-477

23. Chen ML, Failla ML 1989 Degradation of zinc-metallothionein in monolayer cultures of rat hepatocytes. Proc Soc Exp Biol Med 191:130-138 